\title{
Nutritional evaluation of vegetable and mixed crude glycerin in the diet of growing rabbits ${ }^{1}$
}

\author{
Marciana Retore ${ }^{2}$, Claudio Scapinello², Alice Eiko Murakami ${ }^{2}$, Ivan Graça Araujo ${ }^{2}$, Bruna \\ Ponciano Neto $^{2}$, Karla dos Santos Felssner ${ }^{2}$, Joyce Sato ${ }^{2}$, Andréia Fróes Galuci Oliveira ${ }^{2}$ \\ 1 Pesquisa financiada pelo CNPq. \\ 2 Departamento de Zootecnia, Universidade Estadual de Maringá. Av. Colombo, 5.790, 87020-900, Maringá - PR.
}

\begin{abstract}
The objectives of this study were to determine the chemical composition of vegetable and mixed crude glycerin and digestible energy to and evaluate different inclusion levels in rabbit feeding. A total of 108 rabbits were used in the digestibility assay, assigned in a completely randomized design into nine treatments, one reference diet plus eight test diets, where the glycerin types were included at levels of 4, 8, 12 and 16\%, replacing the reference diet roughage. In the performance assay, 180 rabbits were assigned to a completely randomized design into a $2 \times 4$ factorial arrangement (two types of glycerin and four levels of inclusion: 3, 6, 9 and 12\%) plus a reference diet and ten replications. The vegetable and mixed crude glycerin showed digestible energy of 5,099 and 4,953 kcal/kg of dry matter, respectively. Although feed intake decreased linearly with the growing inclusion of both kinds of glycerin during both evaluated periods (from 32 to 50 and 32 to 70 days), performance losses occurred only with the inclusion of vegetable crude glycerin. The inclusion of mixed crude glycerin up to $12 \%$ allowed similar animal performance to the reference diet up to 50 days, unlike vegetable crude glycerin, for which inclusions over $6 \%$ in the diet resulted in poorer performance compared with that obtained with the reference diet. In the total period, differences were not observed for live weight or weight gain of the animals fed both glycerin types. Carcass weight decreased linearly with the inclusion of both glycerin types, with lower values compared with the reference diet only for the two highest levels of glycerin inclusion. Mixed crude glycerin can be included up to the maximum level studied (12\%), while vegetable glycerin can be added up to $6 \%$ in the diet of growing rabbits.
\end{abstract}

Key Words: feeding, nutrition, Oryctolagus cuniculus, total collection of feces

\section{Introduction}

The peculiar digestive system of rabbits allows the inclusion of several agro-industrial byproducts in diets for this species (Mateos \& Vidal, 1996); unlike most nonruminants, rabbits have a functional cecum. The inclusion of grains in the diets of these animals during the growth stage, particularly until 50 days of age, creates limitations in the balancing of complete feeds, especially the starch fraction, as the specific enzyme activity for the digestion of this component increases with age.

Several research studies in the field of animal nutrition have focused on evaluating alternative feed sources, with the main objective of assessing their nutritional value and optimizing their use in animal diets. Glycerin emerges in the market as a byproduct from the biodiesel industry, obtained through catalytic transesterification of oils from different oilseeds, as well as from used cooking oil and animal fat in the presence of methanol or ethanol (Expedito, 2003), representing approximately $10 \%$ of total biodiesel roughage (Dasari et al., 2005). Glycerin types differ according to their degree of industrial processing, in which crude glycerin has a high content of fatty acids and residues such as sodium and potassium, unlike semi-purified glycerin.

Studies on glycerin addition in animal diets have been motivated by the possibility of reducing diet costs, given the vast worldwide availability of this product (Pinto et al., 2005). Additionally, the glycerol contained in glycerin is a promising alternative to replace energy-rich dietary items traditionally used in rabbit diets, due to its high energy level, sweet taste and significant levels of fatty acids. This would reduce starch levels and consequently the risks of digestive problems for rabbits, which usually occur from weaning up to 50 days of age. Nevertheless, Tyson et al. (2004) observed that sodium and impurities in recycled oils and the reagents used in transesterification are the main problems with biodiesel-based glycerin, limiting intake.

The objectives of the present study were to determine the chemical composition and digestible energy of crude vegetable glycerin (from soybean oil) and mixed crude glycerin ( $80 \%$ soybean oil $+20 \%$ animal fat) resulting from the biodiesel production, and to evaluate the different levels of inclusion in the diet on performance and carcass characteristics of growing rabbits. 


\section{Material and Methods}

Two experiments - a digestibility assay and a performance assay - were carried out at the rabbit breeding sector of the Iguatemi Experimental Farm of the Universidade Estadual de Maringá, Paraná, Brazil, between April and November 2009.

A total of 108 New Zealand White rabbits, half male and half female, 45 days of age, were used for the digestibility trial. The specimens were housed individually in metabolism cages featuring automatic nipple drinkers, semi-automatic feeders and a feces collection device. The cages were set inside a shed covered with corrugated asbestos roofing, $3.8 \mathrm{~m}$ high, solid flooring, $30-\mathrm{cm}$ masonry side walls, and the remainder in mesh and plastic curtaining for wind control.

The experimental design was entirely randomized, with nine treatments - one reference diet (Table 1) plus eight test diets, in which crude vegetable and mixed crude glycerin types (Table 2) were included at $4 \%, 8 \%, 12 \%$ and $16 \%$ in replacement of natural matter (NM) in the reference diet, with 12 replications.

Table 1 - Calculated and chemical composition of the reference diet used in the digestibility assay

\begin{tabular}{|c|c|}
\hline Ingredient & Reference feed (\%) \\
\hline Ground corn & 21.85 \\
\hline Stargrass hay & 25.60 \\
\hline Alfalfa hay & 15.00 \\
\hline Wheat bran & 23.38 \\
\hline Soybean meal & 12.00 \\
\hline Calcitic limestone & 0.60 \\
\hline Dicalcium phosphate & 0.40 \\
\hline Salt & 0.40 \\
\hline Mineral + vitamin supplement ${ }^{1}$ & 0.50 \\
\hline DL-Methionine & 0.06 \\
\hline L-Lysine & 0.15 \\
\hline Coccidiostat $^{2}$ & 0.06 \\
\hline Nutrient & Composition (\% DM) \\
\hline Starch $^{3}$ & 21.00 \\
\hline Gross energy, kcal/kg ${ }^{4}$ & 4.288 \\
\hline Digestible energy, kcal/kg4 & 2.375 \\
\hline Neutral detergent fiber ${ }^{4}$ & 44.41 \\
\hline Acid detergent fiber ${ }^{4}$ & 22.27 \\
\hline Crude protein ${ }^{4}$ & 17.24 \\
\hline Calcium & 0.75 \\
\hline Phosphorus & 0.50 \\
\hline Lysine & 0.80 \\
\hline Methionine + cysteine & 0.60 \\
\hline Ether extract ${ }^{4}$ & 2.73 \\
\hline \multicolumn{2}{|c|}{$\begin{array}{l}{ }^{1} \text { Nuvital, composition per kg of product: vit. A - 600,000 IU; vit. D - 100,000 IU; } \\
\text { vit. E - 8,000 mg; vit. K3 - } 200 \mathrm{mg} \text {; vit. B1 - } 400 \mathrm{mg} \text {; vit. B2 - } 600 \mathrm{mg} \text {; vit. } \\
\text { B6 - } 200 \mathrm{mg} \text {; vit. B12 - 2,000 mcg; pantothenic acid - 2,000 mg; choline - } \\
70,000 \mathrm{mg} \text {; Fe - 8,000 mg; Cu - 1,200 mg; Co - } 200 \mathrm{mg} \text {; Mn - 8,600 mg; Zn - } \\
\text { 12,000 mg; I - } 64 \mathrm{mg} \text {; Se - } 16 \mathrm{mg} \text {; methionine - 120,000 mg; antioxidant - } \\
\text { 20,000 mg. } \\
2 \text { Robenidine-based active ingredient (6.6\%). } \\
3 \text { Analyzed at the Campinas Food Technology Institute. } \\
4 \text { Analyzed at the Feeding and Animal Nutrition Laboratory, Department of } \\
\text { Animal Science, UEM. } \\
\text { DM - dry matter. }\end{array}$} \\
\hline
\end{tabular}

Table 2 - Chemical composition of crude vegetable and mixed glycerin, on a dry matter basis

\begin{tabular}{|c|c|c|}
\hline Parameter & $\begin{array}{l}\text { Crude vegetable } \\
\text { glycerin }\end{array}$ & $\begin{array}{l}\text { Mixed crude } \\
\text { glycerin }\end{array}$ \\
\hline Dry matter ${ }^{1}, \%$ & 97.46 & 94.55 \\
\hline Ash $^{1}, \%$ & 4.58 & 4.89 \\
\hline Total fatty acids ${ }^{2}, \%$ & 23.30 & 21.50 \\
\hline Glycerol$^{2}, \%$ & 54.59 & 68.37 \\
\hline Gross energy $^{1}$, kcal $/ \mathrm{kg}$ & 5586 & 5552 \\
\hline Sodium ${ }^{2}, \%$ & 1.66 & 2.10 \\
\hline Chlorine $^{2}$, \% & 0.47 & 0.37 \\
\hline Potassium $^{2}, \%$ & 0.17 & 0.02 \\
\hline Calcium $^{2}, \%$ & 0.08 & 0.09 \\
\hline Phosphorus $^{2}$, \% & 0.21 & 0.18 \\
\hline Crude protein ${ }^{1}, \%$ & 0.05 & 0.05 \\
\hline
\end{tabular}

${ }^{1}$ Analyzed at the Animal Nutrition Laboratory, UEM.

2 Analyzed at the Chemistry Laboratory, UEM.

Both glycerin types were provided by BIOPAR, Rolândia, Paraná, Brazil. The assay lasted 14 days -10 days for animal adjustment to the cages and diet, and four days for feces collection, in accordance with the European Reference Method for in vivo determination of diet digestibility (Perez et al., 1995). Animals were fed ad libitum and had free access to water throughout the entire experiment.

Feces of every animal were collected once a day, in their totality, during the morning, placed in plastic bags and stored in a freezer at $-10^{\circ} \mathrm{C}$. Later, feces were placed in a forced ventilation oven at $55^{\circ} \mathrm{C}$ during 72 hours. Next, after being homogenized, part of the sample was ground in a mill with $1.0-\mathrm{mm}$ screen for dry matter analysis, following Silva \& Queiroz (2002). Gross energy values were assessed using an adiabatic calorimeter (Parr Instrument Co. AC720), according to the procedures described by Silva \& Queiroz (2002).

Digestible dry matter and digestible energy of both glycerin types were obtained by applying the method of Matterson et al. (1965) and the regression method of Adeola \& Ileleji (2009).

In the performance experiment, 180 male and female New Zealand White rabbits between 32 and 70 days of age were housed in galvanized wire cages, featuring automatic drinkers and semi-automatic feeders, set inside a masonry shed covered with clay tiles, $3.2 \mathrm{~m}$ high, solid flooring, $50-\mathrm{cm}$ masonry side walls, and the remainder in mesh and plastic curtaining for wind control. The average low temperature was $19.7^{\circ} \mathrm{C}$, and the average high was $25.9^{\circ} \mathrm{C}$.

The animals were assigned to a completely randomized alignment, with nine treatments and ten replications, featuring two animals (one male and one female) per experimental unit. The treatments consisted of a reference diet, formulated according to nutritional requirements for growing rabbits (De Blas \& Wiseman, 1998) and eight other 
diets, including crude vegetable and mixed glycerin at 3,6 , 9 and $12 \%$ in feed (Table 3 ). The feeds were dry-pelletized, and animals were fed ad libitum and had free access to water throughout the entire experiment.

The feeds and animals were weighed at the start of the experiment, at 32 days of age, 50 days of age and at the end of the experiment (70 days of age). The performance characteristics evaluated were body weight, daily weight gain, daily feed intake, feed-to-gain ratio and cost per kg of body weight gain.

Animals were slaughtered without prior fasting, by stunning followed by cutting of the jugular. The weight of the carcass and edible viscera (heart, liver and kidneys) was measured as well. Carcass weight was determined by weighing the hot carcass including the head and excluding edible viscera.

To verify the economic viability of glycerin inclusion, the equation described by Bellaver et al. (1985), which calculates the average cost of feed per kg of body weight gained, was used. To calculate the costs of the experimental feeds, the prices of supplies in the region of Maringá/PR were, for the month of July, 2010: glycerin, R $\$ 0.04 / \mathrm{kg}$; corn, R\$ $0.25 / \mathrm{kg}$; soybean meal, R\$ $0.54 / \mathrm{kg}$; stargrass hay, R\$ $0.35 / \mathrm{kg}$; alfalfa hay, R\$ $0.90 / \mathrm{kg}$; soybean oil, $\mathrm{R} \$ 1,77 / \mathrm{kg}$; dicalcium phosphate, $\mathrm{R} \$ 1.82 / \mathrm{kg}$; limestone, R\$ 0.22/kg; salt, R \$ 0.48/kg; DL-Methionine, R\$ 14.10/kg; L-lysine $\mathrm{HCl}, \mathrm{R} \$ 6.30 / \mathrm{kg}$; coccidiostat, R\$10.35/kg; vitamin-mineral supplement, $\mathrm{R} \$ 14.90 / \mathrm{kg}$; and inert (sand), $\mathrm{R} \$ 0.05 / \mathrm{kg}$.

The results of the variables studied in the performance assay were analyzed using SAEG (Sistema para Análises Estatísticas, version 9.1) statistical software, according to the following statistical model:

$Y_{i j k}=b_{0}+T i+b_{1 i}(N i j-\tilde{N} i)+b_{2 i}(N i j-\tilde{N} i)+F A+e_{i j k}$ $\mathrm{Y}_{\mathrm{ijk}}=$ variable measured in experimental unit $k$, fed diet type $i$, containing level $j$ of crude vegetable or mixed glycerin; $\mathrm{b}_{0}=$ overall constant; $\mathrm{Ti}=$ effect of feed type $i$, with $\mathrm{i} 1$ = reference feed, $\mathrm{i} 2$ = feeds containing crude vegetable glycerin, and i 3 = feeds containing mixed crude glycerin; $\mathrm{b}_{1 \mathrm{i}}=$ linear regression coefficient as a function of

Table 3 - Proximate and chemical composition of the experimental feeds for rabbits of 32 to 70 days of age

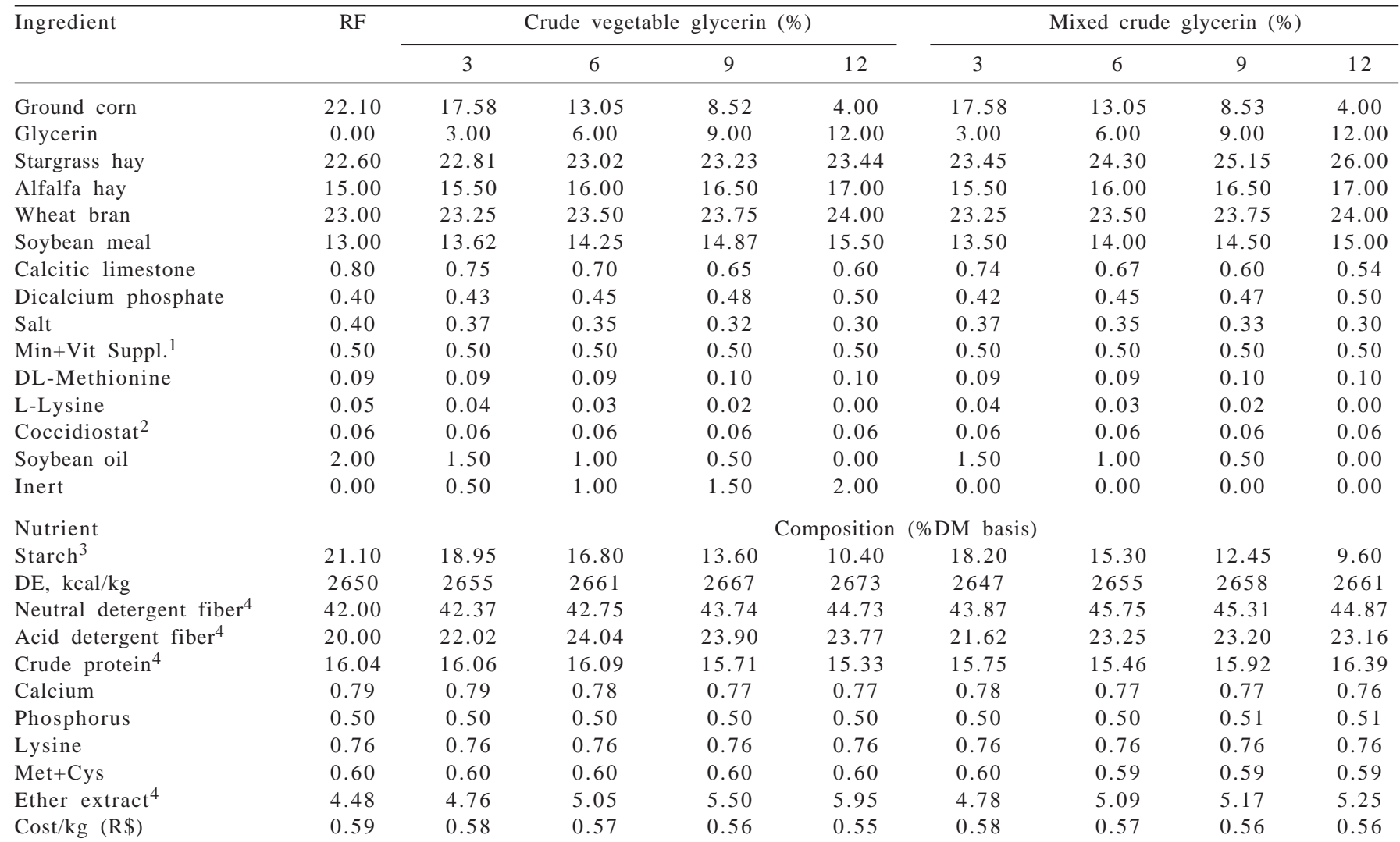

RF - Reference feed; DE - digestible energy; DM - dry matter.

${ }^{1}$ Nuvital, composition per kg of product: vit. A - 600,000 IU; vit. D - 100,000 IU; vit. E - 8,000 mg; vit. K3 - 200 mg; vit. B1 - 400 mg; vit. B2 - 600 mg; vit. B6 200 mg; vit. B12 - 2,000 mcg; pantothenic acid - 2,000 mg; choline - 70,000 mg; Fe - 8,000 mg; Cu - 1,200 mg; Co - 200 mg; Mn - 8,600 mg; Zn - 12,000 mg; I $64 \mathrm{mg}$; Se - $16 \mathrm{mg}$; methionine - 120,000 mg; antioxidant - 20,000 mg.

2 Robenidine-based active principle (6.6\%).

3 Analyzed at the Campinas Food Technology Institute.

${ }^{4}$ Analyzed at the Feeding and Animal Nutrition Laboratory, Department of Animal Science, UEM. 
glycerin level $j$ in type $i$ feed, for every $i$ different than 1 ; $\mathrm{b}_{2}=$ quadratic regression coefficient as a function of glycerin level $j$ in type $i$ feed, for every $i$ different than $1 ; \mathrm{Nij}=$ level $j$ of glycerin added in type $i$ feed, for every $i$ different than 1 ; $\tilde{\mathrm{N}} \mathrm{i}$ = average level of glycerin added in in type $i$ feed, for every $i$ different than 1; FA = lack of fit of the regression model; $\mathrm{e}_{\mathrm{ij}}=$ random error associated with each observation.

The Dunnett test $(\mathrm{P}<0.05)$ was applied to compare the results obtained using the reference diet with those obtained from each of the glycerin inclusion levels.

\section{Results and Discussion}

Applying the method of Adeola \& Ileleji (2009), regression equations to obtain digestible energy values for crude vegetable glycerin and mixed crude glycerin were, respectively, $\mathrm{Y}=-1.6792+5098.5 \mathrm{X}, \mathrm{R}^{2}=0.98$ and $\mathrm{Y}=4.1581$ $+4953.1 \mathrm{X}, \mathrm{R}^{2}=0.98$, indicating that the values of digestible energy for the studied glycerin types were, respectively, 5,098 and $4,953 \mathrm{kcal} / \mathrm{kg}$ of dry matter. The digestibility coefficients of gross energy for the glycerin types were, respectively, $91.27 \%$ and $89.22 \%$. To obtain digestible dry matter values for both glycerin types, the equations were, respectively, $\mathrm{Y}=-0.0871+87.769 \mathrm{X}, \mathrm{R}^{2}=0.94$ and $\mathrm{Y}=0.0723$ $+86.153 \mathrm{X}, \mathrm{R}^{2}=0.98$, showing that digestible dry matter values were respectively, $87.77 \%$ and $86.15 \%$, and that the digestibility coefficients of dry matter were $90.06 \%$ and $91.12 \%$, respectively.

Lammers et al. (2008), working with glycerin containing 86.95\% glycerol for growing swine, found coefficients between $89 \%$ and $92 \%$ for energy digestibility, similar to the values found in the present study, with gross glycerin energy of 3,625 kcal/kg. For poultry, glycerin energy digestibility stayed around 75\% (Simon et al., 1996), lower than the values found in the present study. According to Bartlet \& Schneider (2002), gross energy yield from glycerol by animals can vary depending on the percentage of glycerol employed in the diet. Additionally, other factors such as age and animal species can also influence the energy values obtained for glycerol. For growing rabbits, the main objective of glycerin inclusion is to replace part of the corn present in the diet, to prevent a large quantity of starch from entering the cecum. Corn features gross energy of 3,925 kcal/kg (Rostagno et al., 2005) and digestibility coefficient of gross energy close to $100 \%$ for rabbits (Blas \& Gidenne, 1998).

In the period from 32 to 50 days of age, an interaction was observed $(\mathrm{P}<0.05)$ between types and levels of glycerin included in the diet only for body weight at 50 days of age and daily weight gain from 32 to 50 days of age (Table 4). The increasing addition of crude vegetable glycerin alone linearly reduced $(\mathrm{P}<0.05)$ body weight and daily weight gain of animals. Even though feed intake also decreased linearly $(\mathrm{P}<0.05)$ with the increasing inclusion of both glycerin types, performance losses occurred only with the inclusion of crude vegetable glycerin. Perhaps these results are due to the presence of only long-chain fatty acids in crude vegetable glycerin, which require longer to be oxidized compared with those present in mixed crude glycerin. Because it contains both short- and long-chain fatty acids, the latter may have made energy available more easily to tissues, favoring animal weight gain. Despite these results, when applying the Dunnett test, only animals receiving diets with $9 \%$ and $12 \%$ inclusion of crude vegetable glycerin

Table 4 - Estimated averages and coefficient of variation (CV) of performance characteristics and cost of feed per kg of body weight gain of rabbits fed, from 32 to 50 days of age, diets containing different inclusion levels of crude vegetable glycerin (CVG) and mixed crude glycerin (MCG)

\begin{tabular}{|c|c|c|c|c|c|c|c|c|c|c|c|c|c|c|c|}
\hline \multirow[t]{2}{*}{ Glycerin (\%) } & \multicolumn{3}{|c|}{ BW 50 (g) } & \multicolumn{3}{|c|}{ DWG 32-50 (g) } & \multicolumn{3}{|c|}{ DFI 32-50 (g) } & \multicolumn{3}{|c|}{ FGR $32-50$} & \multicolumn{3}{|c|}{ Cost/kg WG 32-50 } \\
\hline & CVG & MCG & Average & CVG & MCG & Average & CVG & MCG & Average & CVG & MCG & Average & CVG & MCG & Average \\
\hline RF & \multicolumn{2}{|c|}{1497} & & \multicolumn{2}{|c|}{39.42} & & \multicolumn{2}{|c|}{112.14} & & \multicolumn{2}{|c|}{2.87} & & \multicolumn{2}{|c|}{1.69} & \\
\hline 3 & 1445 & 1468 & 1456 & 36.53 & 37.83 & 37.18 & 114.46 & 107.31 & 110.88 & 3.21 & 2.86 & 3.03 & 1.85 & 1.66 & 1.75 \\
\hline 6 & 1506 & 1454 & 1480 & 39.88 & 37.03 & 38.46 & 112.84 & 108.76 & 110.80 & 2.84 & 2.94 & 2.89 & 1.62 & 1.68 & 1.65 \\
\hline 9 & $1404^{*}$ & 1482 & 1443 & $34.27^{*}$ & 38.58 & 36.42 & 107.23 & 109.43 & 108.33 & 3.18 & 2.86 & 3.02 & 1.79 & 1.60 & 1.69 \\
\hline 12 & $1391^{*}$ & 1471 & 1431 & $33.52^{*}$ & 38.00 & 35.76 & 101.81 & 104.68 & $103.24^{*}$ & 3.11 & 2.78 & 2.94 & 1.71 & 1.56 & 1.63 \\
\hline Average & 1436 & 1469 & & 36.05 & 37.86 & & 109.08 & 108.47 & & $3.08 \mathrm{~b}$ & $2.86 \mathrm{a}$ & & $1.74 \mathrm{~b}$ & $1.62 \mathrm{a}$ & \\
\hline Interaction & \multicolumn{2}{|c|}{$* *$} & & \multicolumn{2}{|c|}{$* *$} & & \multicolumn{2}{|c|}{ ns } & & \multicolumn{2}{|c|}{ ns } & & \multicolumn{2}{|c|}{ ns } & \\
\hline Regression & Linear & ns & & Linear & ns & & & & Linear & & & ns & & & ns \\
\hline CV & \multicolumn{2}{|c|}{6.58} & & \multicolumn{2}{|c|}{12.35} & & \multicolumn{2}{|c|}{9.02} & & \multicolumn{2}{|c|}{13.24} & & \multicolumn{2}{|c|}{12.95} & \\
\hline
\end{tabular}

RF - Reference feed; BW50 - Body weight at 50 days; DWG 32-50 - daily weight gain at 32-50 days; DFI 32-50 - daily feed intake at 32-50 days; FGR 32-50 - feed-togain ratio at 32-50 days; ns - non-significant; Cost/kg WG32-50 - feed cost, in Brazilian Reals (R\$), for each kg of weight gain from animals at 32 to 50 days of age. Different letters in the same row differ by F-test $(\mathrm{P}<0.05)$

*Differ from the reference by Dunnett test $(\mathrm{P}<0.05)$.

** Significant interaction $(\mathrm{P}<0.05)$.

BW 50: $\mathrm{Y}=1500.69-8.7112 \mathrm{X}, \mathrm{R}^{2}=0.44$

DWG 32-50: $\mathrm{Y}=39.6330-0,4839 \mathrm{X}, \mathrm{R}^{2}=0.44$

DFI 32-50: $\mathrm{Y}=114.5227-0.8358 \mathrm{X}, \mathrm{R}^{2}=0.82$. 
showed body weight and weight gain lower $(\mathrm{P}<0.05)$ than those obtained in animals fed the reference diet.

For daily feed intake, applying Dunnett's test $(\mathrm{P}<0.05)$, only the animals fed $12 \%$ glycerin in the diet had intake lower $(\mathrm{P}<0.05)$ than that observed for animals fed the reference diet. Although the feeds containing glycerin inclusion were formulated with decreasing addition of salt, this was not enough to avoid excess sodium in the diets, as glycerin has high levels of this mineral in its composition (Table 2 ). In this case, animals with $12 \%$ glycerin inclusion in the diet felt that effect most severely.

The higher daily weight gain observed for animals that received the diets containing mixed crude glycerin provided the best feed-to-gain ratios $(\mathrm{P}<0.05)$, and consequently the lowest feed cost per kg of weight gain during that period $(\mathrm{P}<0.05)$, as there was no change in feed intake between the types of glycerin used. This shows that mixed crude glycerin was more efficient compared with crude vegetable glycerin. Given that both have quite similar compositions in terms of energy, digestibility and mineral levels, the reason for this superior efficiency may be attributed to the characteristics of fatty acids present in each; mixed crude glycerin has both short- and long-chain fatty acids, which allowed quick energy supply to cells, maintained by the slower oxidation of long-chain fatty acids. Crude vegetable glycerin, due to the longer chain of its fatty acids, provided energy more slowly, reflecting in lower weight gain and, consequently, lower body weight at 50 days of age.

No differences were observed $(\mathrm{P}<0.05)$ for either feedto-gain ratio or feed cost with the growing addition of both glycerin types in the diet. However, the feed-to-gain ratio was better and cost per kg was lower for the animals fed mixed crude glycerin, as feed intake did not differ between the types of byproduct used. Weight gain, however, was higher for animals fed mixed crude glycerin diets.

Groesbeck et al. (2008), while testing levels of 3\%, $6 \%$ and $12 \%$ of crude glycerin for post-weaning piglets, achieved increased feed intake, which was not observed in the present research. Lammers et al. (2007), after including $5 \%$ and $10 \%$ crude glycerin in the diets of postweaning piglets, did not observe any effect on animal performance.

In the present study, inclusion of up to $12 \%$ of mixed crude glycerin resulted in similar animal performance to the reference diet up to 50 days of age, unlike crude vegetable glycerin. The high levels of sodium present in the glycerin types (Table 2) may have been the cause of the linear reduction in animal feed intake. For this reason, Menten et al. (2008), while evaluating soybean meal supplemented with $10 \%$ glycerin $(81.47 \%$ glycerol and $2.40 \%$ sodium) in broiler diets, recommended the necessary nutritional adjustments in terms of energy, aminoacids and sodium, so that the feed in question could be used during the rearing period without affecting bird performance.

As also observed for the period between 32 and 50 days of age, an interaction $(\mathrm{P}<0.05)$ was observed between the levels and types of glycerin only for body weight at 70 days and daily weight gain throughout the experimental period, from 32 to 70 days of age (Table 5). The increasing addition of crude vegetable glycerin alone linearly reduced $(\mathrm{P}<0.05)$ body weight at 70 days and daily weight gain from 32 to 70 days of age.

Table 5 - Estimated averages and coefficient of variation (CV) of performance characteristics and cost of feed per kg of body weight gain of rabbits fed, from 32 to 70 days of age, diets containing different inclusion levels of crude vegetable glycerin (CVG) and mixed crude glycerin (MCG)

\begin{tabular}{|c|c|c|c|c|c|c|c|c|c|c|c|c|c|c|c|}
\hline \multirow[t]{2}{*}{ Glycerin (\%) } & \multicolumn{3}{|c|}{ BW 70 (g) } & \multicolumn{3}{|c|}{ DWG 32-70 (g) } & \multicolumn{3}{|c|}{ DFI 32-70 (g) } & \multicolumn{3}{|c|}{ FGR 32-70 } & \multicolumn{3}{|c|}{ Cost/kg WG 32-70 } \\
\hline & CVG & MCG & Average & CVG & MCG & Average & CVG & MCG & Average & CVG & MCG & Average & CVG & MCG & Average \\
\hline RF & \multicolumn{2}{|c|}{2079} & & \multicolumn{3}{|c|}{34.00} & \multicolumn{2}{|c|}{123.13} & & \multicolumn{2}{|c|}{3.65} & \multicolumn{4}{|c|}{2.15} \\
\hline 3 & 2044 & 2052 & 2048 & 33.06 & 33.29 & 33.17 & 126.25 & 120.38 & 123.31 & 3.85 & 3.63 & 3.74 & 2.23 & 2.11 & 2.17 \\
\hline 6 & 2088 & 2029 & 2058 & 34.24 & 32.67 & 33.45 & 122.71 & 118.78 & 120.74 & 3.59 & 3.66 & 3.62 & 2.05 & 2.08 & 2.06 \\
\hline 9 & $1974^{*}$ & 2059 & 2016 & $31.24^{*}$ & 33.47 & 32.35 & 119.13 & 119.85 & 119.49 & 3.85 & 3.61 & 3.73 & 2.16 & 2.02 & 2.09 \\
\hline 12 & 1978 & 2045 & 2011 & $31.33^{*}$ & 33.11 & 32.22 & 111.33 & 113.68 & $112.50^{*}$ & 3.59 & 3.46 & 3.52 & 1.97 & 1.94 & $1.95^{*}$ \\
\hline Average & 2021 & 2046 & & 32.47 & 33.13 & & 119.85 & 118.17 & & $3.72 b$ & $3.59 \mathrm{a}$ & & $2.10 \mathrm{~b}$ & $2.04 \mathrm{a}$ & \\
\hline Interaction & \multicolumn{2}{|c|}{$* *$} & & \multicolumn{3}{|c|}{$* *$} & \multicolumn{2}{|c|}{ ns } & & \multicolumn{3}{|c|}{ ns } & \multicolumn{2}{|c|}{ ns } & \\
\hline Regression & Linear & ns & & Linear & ns & & & & Linear & & & ns & & & Linear \\
\hline $\mathrm{CV}$ & \multicolumn{3}{|c|}{5.94} & \multicolumn{3}{|c|}{9.68} & \multicolumn{2}{|c|}{6.39} & & \multicolumn{2}{|c|}{9.57} & \multicolumn{4}{|c|}{9.56} \\
\hline \multicolumn{16}{|c|}{$\begin{array}{l}\text { RF - Reference feed; BW70 - Body weight at } 70 \text { days; DWG 32- } \\
\text { gain ratio at } 32-70 \text { days; ns - non-significant; Cost } / \mathrm{kg} \text { WG32-70 } \\
\text { Different letters in the same row differ by the F-test }(\mathrm{P}<0.05) \text {. } \\
\text { *Differ from the reference by the Dunnett test }(\mathrm{P}<0.05) \text {. } \\
\text { **Significant interaction }(\mathrm{P}<0.05) \text {. } \\
\text { BW 70: } \mathrm{Y}=2097.34-10.2525 \mathrm{X}, \mathrm{R}^{2}=0.53 \text {. } \\
\text { DWG 32-70: } \mathrm{Y}=34.4750-0.2698 \mathrm{X}, \mathrm{R}^{2}=0.53 \text {. } \\
\text { DFI 32-70: } \mathrm{Y}=127.3094-1.1137 \mathrm{X}, \mathrm{R}^{2}=0.88 . \\
\text { Cost/kg WG 32-70: } \mathrm{Y}=2.2222-0.0203 \mathrm{X}, \mathrm{R}^{2}=0.83 \text {. }\end{array}$} \\
\hline
\end{tabular}


Although feed intake also decreased linearly $(\mathrm{P}<0.05)$ with the inclusion of both types of glycerin, performance losses occurred only with the inclusion of crude vegetable glycerin, which is probably linked to the chain structure of the fatty acids present in that type of glycerin, described previously. Applying the Dunnett test, values were lower $(\mathrm{P}<0.05)$ than those obtained with animals fed the reference diet for body weight at 70 days for the diet with $9 \%$ inclusion of crude vegetable glycerin and daily weight gain from 32 to 70 days of age for the diets with $9 \%$ and $12 \%$ inclusion of crude vegetable glycerin.

Although the diets featuring $9 \%$ and $12 \%$ crude vegetable glycerin inclusion provided the worst animal performance compared with those fed the reference diet, no differences were observed $(\mathrm{P}>0.05)$ for body weight and weight gain during the total experimental period for the animals fed both types of crude glycerin - vegetable and mixed.

For daily feed intake, applying the Dunnett test $(\mathrm{P}<0.05)$, only the animals fed $12 \%$ glycerin in the diet had intake lower $(\mathrm{P}<0.05)$ than that observed for the animals fed the reference diet, proving that excessive sodium in the diet indeed affected animal intake at the highest level of glycerin inclusion. Prior to adding this byproduct to the diet, the necessary nutritional adjustments must be made to prevent the excess of this mineral from limiting intake.

Although there were no differences in performance or feed intake between the groups fed the different glycerin types, the animals receiving the diets containing mixed crude glycerin showed the best feed-to-gain ratios $(\mathrm{P}<0.05)$ and, consequently, the lowest feed cost per $\mathrm{kg}$ of weight gain during that period $(\mathrm{P}<0.05)$ compared with animals that received the diets containing crude vegetable glycerin.
The addition of growing levels of both glycerin types did not alter the feed-to-gain ratio ( $\mathrm{P}>0.05)$; nevertheless, a linear reduction $(\mathrm{P}<0.05)$ was observed in feed cost per $\mathrm{kg}$ of weight gain for both glycerin types, added in growing level to the diets. It should also be stressed that, when applying the Dunnett test $(\mathrm{P}<0.05)$, only the animals fed $12 \%$ of both glycerin types in the diet showed feed cost lower $(\mathrm{P}<0.05)$ than that observed for animals treated with the reference diet. This result is justified by the reduction in feed intake of both glycerin types compared with the animals under the reference diet without changes in animal weight gain, thus allowing lower production costs with $12 \%$ inclusion of glycerin in the diet.

Cerrate et al. (2006) evaluated the inclusion of 5\% and $10 \%$ of crude glycerin in broiler feeds, and reported that the $10 \%$ level adversely affected feed intake, final weight, and, consequently, the feed-to-gain ratio of broilers. This was attributed to the lower quality of pelleted feed, which was not the reason observed in the present study, but rather excessive sodium.

It is important to remark that during the evaluated period, from 32 to 70 days of age, no animal deaths occurred.

No interaction ( $\mathrm{P}>0.05)$ was observed for carcass weight or edible viscera weight for rabbits fed different inclusion levels of crude vegetable glycerin and mixed glycerin types in the diet, slaughtered at 70 days of age (Table 6). However, carcass weight was higher $(\mathrm{P}<0.05)$ for the animals receiving the diet with mixed crude glycerin inclusion, although the final weight of animals (70 days) did not vary between the groups receiving the different glycerin types. What did contribute to this fact was possibly the greater increase, although numeric, in the final weight of animals fed diets containing crude vegetable glycerin. A linear reduction

Table 6 - Estimated averages and coefficient of variation (CV) of carcass weight and edible viscera weight of rabbits fed, from 32 to 70 days of age, diets containing different inclusion levels of crude vegetable glycerin (CVG) and mixed crude glycerin (MCG), slaughtered at 70 days of age

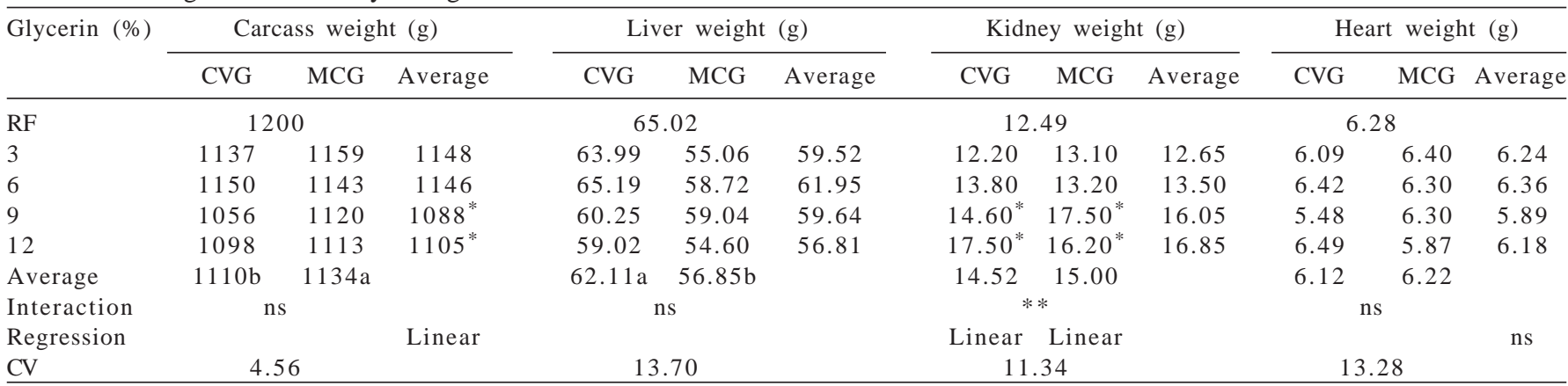

RF - Reference feed; TCR - Thoracic-cervical region; ns - non-significant.

Different letters in the same row differ by $\mathrm{F}$-test $(\mathrm{P}<0.05)$

* Differ from the reference by the Dunnett test $(\mathrm{P}<0.05)$

** Significant interaction $(\mathrm{P}<0.05)$.

Carcass: $\mathrm{Y}=1168.74-6.2117 \mathrm{X}, \mathrm{R}^{2}=0.63$

Kidneys: $\mathrm{Y}=10.3492+0.5568 \mathrm{CVG}, \mathrm{R}^{2}=0.94$ and $\mathrm{Y}=11.5992+0.4535 \mathrm{MCG}, \mathrm{R}^{2}=0.64$ 
$(\mathrm{P}<0.05)$ was also observed for this variable as inclusion levels of both glycerin types increased in the diets. Despite this linear decrease in carcass weight, when the Dunnett test $(\mathrm{P}<0.05)$ was applied, only the carcass weight of animals fed the diets containing $9 \%$ and $12 \%$ of the glycerin types were lower than those obtained with reference feed, following the behavior for body weight at 70 days at these same levels, although non-significant. In the present study, the inclusion of $3 \%$ and $6 \%$ of glycerin did not influence the weight of cuts, compared with the reference feed.

An interaction was observed only between glycerin types and inclusion levels in the diets for kidney weight. Despite this interaction, the growing inclusion of both glycerin types in the diets linearly increased $(\mathrm{P}<0.05)$ the weight of that organ. In spite of the linear increase, it could be observed by applying the Dunnett test, that only the animals receiving the diets containing $9 \%$ and $12 \%$ glycerin had higher kidney weight $(\mathrm{P}<0.05)$ compared with animals fed the reference $\operatorname{diet}(\mathrm{P}<0.05)$. This weight gain is possibly related to the high levels of minerals present in the glycerin types (Table 2), requiring greater functioning of that organ to maintain electrolyte balance, increasing fluid retention.

Glycerol is generated in the body during triacylglycerol hydrolysis in fatty acids. As such, in addition to the glycerol present in animal diets, fatty tissues are the main source of glycerol. Depending on the animal energy needs, glycerol is metabolized either in the liver to provide energy to the cells of that organ whenever necessary, or through glycogenesis, so the liver can produce glucose for use by the rest of the body (Dasari, 2007). Therefore, any excessive glycerol provided in animal diets can induce anatomical, physiological and biochemical adaptations, especially in the liver, possibly affecting the kidneys as well (Cryer \& Bartley, 1973). This was verified by Lin et al. (1976), who studied the effect of glycerin on lipogenic activity in rats and chicken. They observed that adding $20 \%$ glycerin in rat diets for three weeks increased liver weight and caused a marked increase in the activity of lipogenic enzymes in that organ. Conversely, no changes in liver weight were observed in chickens, and the activity of lipogenic enzymes actually decreased.

In the present study, liver weight did not change with growing glycerin inclusion in the diet, showing that glycerin can cause species- and organ-specific responses, requiring new study methodologies to assure that glycerin continues to be regarded as a general-use ingredient in animal feeding.

No difference $(\mathrm{P}>0.05)$ was observed in heart weight, either between glycerin types or for inclusion of increasing levels in the diets. Silva (2006), working with rabbits of two different weaning ages (28 and 35 days), slaughtered at 70 days, observed much higher liver weight ( $91.70 \mathrm{~g}$ ) than that found in this research, but similar weights for kidneys and heart (14.10 and $7.50 \mathrm{~g}$, respectively).

\section{Conclusions}

Crude vegetable glycerin and mixed crude glycerin showed digestible energy of 5,099 and 4,953 kcal/kg of dry matter, respectively, both proving to be high energy value sources. Mixed crude glycerin can be included at the maximum studied level of $12 \%$, whereas crude vegetable glycerin can be added at $6 \%$ in tdiets for growing rabbits, analyzing the cost-benefit in order to evaluate the best level to be used.

\section{References}

ADEOLA, O.; ILELEJI, K.E. Comparison of two diet types in the determination of metabolizable energy content of corn distillers dried grains with soluble for broiler chickens by the regression method. Poultry Science, v.88, p.579-585, 2009.

BARTLET, J.; SCHNEIDER, D. Investigation on the energy value of glycerol in the feeding of poultry and pig. Union for the Promotion of Oilseeds-Schriften Heft, v.17, p.15-36, 2002.

BELLAVER, C.; FIALHO, E.T.; PROTAS, J.F.S. et al. Radícula de malte na alimentação de suínos em crescimento e terminação. Pesquisa Agropecuária Brasileira, v.20, n.8, p.969-974, 1985.

BLAS, E.; GIDENNE, T. Digestion of starch and sugars. In: DE BLAS, C.; WISEMAN, J. (Eds.). The nutrition of rabbit. Wallingford: CABI Publishing, 1998. p.17-38.

CERRATE, S.; YAN, F.; WANG, Z. et al. Evaluation of glycerine from biodiesel production as a feed ingredient for broilers. International Journal of Poultry Science, v.5, n.11, p.1001-1007, 2006.

CRYER, A.; BARTLEY, W. Studies of the adaptation of rats to a diet high in glycerol. International Journal of Biochemistry, v.4, p.293-308, 1973.

DASARI, M.A.; KIATSIMKUL, P.P.; SUTTERLIN, W.R. et al. Low-pressure hydrogenolysis of glycerol to propylene glycol. Applied Catalysis A: General, v.281, p.225-231, 2005.

DASARI, M. Crude glycerol potential described. Feedstuffs, v.79, 2007, p.1-3.

DE BLAS, C.; WISEMAN, J. The nutrition of the rabbit. London: Cab Publishing, p.241-253, 1998.

EXPEDITO, J.S. Biodiesel: uma aventura tecnológica num país engraçado. Salvador: Rede Baiana de Biocombustíveis, 2003. 68p.

GROESBECK, C.N.; MICKINNEY, L.J.; DEROUCHEY, J.M. Effect of crude glycerol on pellet Mill production and nursey pig growth performance. Journal of Animal Science, v.85, suppl.1, p.201-201, 2008.

LAMMERS, P.; HONEYMAN, M.; KERR, B.J. et al. Growth and performance of nursery pigs fed crude glycerol. Ames: Iowa State University Animal Industry Report, 2007. 3p. (Supplement).

LAMMERS, P.J.; KERR, B.J.; HONEYMAN, M.S. et al. Nitrogencorrected apparent metabolizable energy value of crude glycerol for laying hens. Poultry Science, v.87, p.104-107, 2008. 
LIN, M.H.; ROMSOS, D.R.; LEVEILLE, G.A. Effect of glycerol on lipogenic enzyme activities and on fatty acids synthesis in the rat and chicken. Journal of Nutrition, v.106, p.1668-1677, 1976.

MATEOS, G.G.; VIDAL, J.P. Diseño de programas alimenticios para conejos: aspectos teóricos y formulación prática. Cuniculture, v.21, n.119, p.27-42, 1996.

MATTERSON, L.D.; POTTER, L.M.; SINGSEN, E.P. The metabolizable energy of feed ingredients for chickens. Research Reproduction, n.7, p.3-11, 1965.

MENTEN, J.F.M.; PEREIRA, P.W.Z.; RACANICCI, A.M.C. et al. Avaliação da glicerina proveniente do biodiesel como ingrediente para rações de frangos de corte. In: CONFERÊNCIA APINCO 2008 DE CIÊNCIA E TECNOLOGIA AVÍCOLAS, 2008, Santos. Anais... Campinas: Fundação APINCO de Ciência e Tecnologia Avícolas, 2008. p.66.

PEREZ, J.M.; LEBAS, F.; GIDENNE, T. et al. European reference method for in vivo determination of diet digestibility in rabbits. World Rabbit Science, v.3, n.1, p.41-43, 1995.

PINTO, A.C.; GUARIEIRO, L.L.N.; RESENDE, M.J.C. et al. Biodiesel: an overview. Journal of the Brazilian Chemical Society, v.16, n.6, p.1313-1330, 2005.
ROSTAGNO, H.S.; ALBINO, L.F.T.; DONZELE, J.L. et al. Tabelas brasileiras para aves e suínos: composição de alimentos e exigências nutricionais. 1.ed. Viçosa, MG: UFV, 2005. 186p.

SILVA, D.J.; QUEIROZ, A.C. Análise de alimentos - métodos químicos e biológicos. 3.ed. Viçosa, MG: Universidade Federal de Viçosa, 2002. 235p.

SILVA, W.R. Avaliação do desempenho de coelhas submetidas a diferentes níveis energéticos e períodos de lactação e de coelhos em crescimento alimentados com diferentes perfis de nutrientes. 2006. 86f. (Dissertação (Mestrado em Zootecnia) - Universidade Estadual de Maringá, Maringá.

SIMON, A.; BERGNER, H.; SCHWABE, M. Glycerol - feed ingredient for broiler chickens. Archives of Animal Nutrition, v.49, p.103-112, 1996.

TYSON, K.S.; BOZELL, J.; WALLACE, R. et al. [2004]. Biomass oil analysis: research needs and recommendations. Technical Report National Renewable Energy Laboratory Golden, Colorado, USA. Available at: <http://www.nrel.gov/docs/ fy04osti/34796.pdf>. Accessed on: Aug. 29, 2009. 